\title{
A Study on influence of organic ligands on migration of heavy metals through compacted clayey soil
}

\author{
Sudheerkumar Yantrapalli ${ }^{1}$ **, Hari Krishna $\mathrm{P}^{2}$, Srinivas $\mathrm{K}^{3}$ \\ ${ }^{1}$ Geotechnical Engineering Division , NIT Warangal, India \\ ${ }^{2}$ Department of Civil Engineering, NIT Warangal, India
}

* Corresponding author : sudheerkumar@student.nitw.ac.in

Tel.: +919866938516

Received: 27 Des, 2017. Revised : 16 Apr, 2018, Accepted: 24 May, 2018, Published: 1 June 2018

DOI: 10.24273/jgeet.2018.3.2.1036

\begin{abstract}
This paper presents the feasibility study on utilization of locally available clayey soil as Compacted Clay Liner based on its contaminant migration capacity under the presence of organic chemical EDTA (Ethylene Diamine Tetra acetic Acid) which is abundantly released into the environment. Lead, Nickel, cadmium and chromium ions was selected as contaminants and its migration properties are assessed by conducting column studies with a single and multiple heavy metal solution with the EDTA. From the experimental investigations, it is revealed that with the presence of EDTA, the contaminant breakthrough time get reduced due to soluble metal - EDTA complex formation. At $\mathrm{pH} 2$, interaction with multi metal, the mobility was increased and the order of mobility was observed as $\mathrm{Cr}>\mathrm{Cd}>\mathrm{Ni}>\mathrm{Pb}$. With the presence of EDTA in multi metal system at $\mathrm{pH} 2$, the order of the mobility was $\mathrm{Cr}>\mathrm{Ni}>\mathrm{Cd}>\mathrm{Pb}$ and at $\mathrm{pH} 7$ the mobility of heavy metals were increased the order was $\mathrm{Cr}>\mathrm{NI}>\mathrm{Pb}>\mathrm{Cd}$. This study reveals that locally available clayey soil is capable of retaining heavy metals and it may be used as a compacted clay liner, where organic chemical like (EDTA) ingression is present.
\end{abstract}

Keywords: Clayey soil, Compacted Clay Liner, Lead, Nickel, Cadmium, Chromium, EDTA, Column studies

\section{Introduction}

The rapid growth of industrialization and urbanization, the amount as well as the rate of generation of waste is increasing substantially, thereby insisting us to think about the need of disposal of waste (consisting mainly house hold and industrial rejects) in an effective and scientific way (Rajesh et al., 2014). Basically, the disposed waste comprised of different types of toxic and non-toxic elements i.e. heavy metals, organic and inorganic matter etc. of them, the more emphasis is given to heavy metals which are mainly responsible for contamination of surface and subsurface environment (Marina et al., 2003, Kumar and Singh., 2005; Li et al., 2012). Further, it was observed that, most of the causes of ground water pollution initiated from the landfill area where there was no provision of installing engineered liners and leachate collection system (Goodall and Quigley., 1977). To prevent such surface and subsurface contamination, it is necessary to place a barrier the between waste and surrounding environment (Mulligan et al., 2001). To construct a barrier or liner, with commercially available materials such as bentonite or geo-membranes can be used (Gleason et al 1997). But, using those material landfill lining system may lead to cracking up under elevated temperature and also under aggressive chemicals in landfill. Koerner and Daniel (1993) and Rowe (2005) observed that, using geo-membrane as a bottom liner seems to be ineffective due to the improper handling and placement. High leakage rate has been observed through geo-membrane and geo synthetic clay liner due to tear created in the membrane caused by the improper handling and placing. So, to counter these problems, if locally available clayey soil meeting the basic requirements of landfill liner such as hydraulic conductivity, and good adsorption capacity, it is possible to construct a secure landfill (Mohamedzein et al., 2005).

Past findings revealed that the studies on the soil leachate compatibility mainly focused on how heavy metals are being adsorbed by the soil and migrated through. But the adsorption of heavy metals by the soil and migration of heavy metals is unlike under the presence of organic chemicals. The very common organic chemical which is disposed of from household detergents and textile industries is EDTA (Ethaline Diamine tetra Acetic Acid). The volume of EDTA disposed into the environment from these sources is almost $51 \%$ (Oviedo and Rodríguez, 2003). The government of Telangana (India) proposed to construct textile industry beside the existing landfill leachate pond. So, disposal of EDTA along with textile industrial waste water on leachate pond causes desorption of metal ions which is retained by the soil then causes the ground water contamination problems in and around landfill areas (Oviedo and Rodríguez, 2003; Chen et 
al., 2008). Though many researchers have focused on the utilization of EDTA for extraction of heavy metals from the soils and sediments (Reddy et al. 2003; Reddy et al. 2010), but excessive utilization of EDTA may pose severe environmental problems (Peters and Shem, 1992; Peters., 1999). So, utilization of EDTA needs to be scrutinized because this EDTA can influence the mobility of heavy metals through the soil. And the presence of organic and inorganic chemicals in waste water or in landfill leachate may seriously affect the adsorption of various metal ions (Bowers and Huang, 1985). There is a little information available about adsorption behavior of heavy metals with known parameters like type of soil and concentration of organic chemicals present and $\mathrm{pH}$ of the leachate.

In the present study, efforts were being made to understand the migration of heavy metal ions through the clayey soil with the presence of EDTA. Column studies were performed to calculate the diffusion coefficient from the column data obtained. So, by obtaining these parameters, it may be possible to design safe and secure compacted clay liner systems where the organic chemicals present in the landfill leachate.

\section{Transport of chemicals through soil}

Transport of chemicals through the soil consists of three main process namely, advective transport, diffusive transport and chemical reactions between the chemicals and the soil. The concentration profile of a chemical in the soil medium in 1- D transport equation which can be expressed in equation 1 ,

$$
\frac{\partial \mathrm{C}}{\partial \mathrm{t}}=\frac{\mathrm{D}}{\mathrm{R}} \frac{\partial \mathrm{C}}{\partial \mathrm{Z}^{2}}-\frac{\mathrm{Vs}}{\mathrm{R}} \frac{\partial \mathrm{C}}{\partial \mathrm{Z}}
$$

The solution of the 1-D transport equation was proposed by Ogata and Banks (1961) and rearranged by Shackelford (1994); Mohammad and Anita (1998) for landfill liner application. The solution was expressed in terms of a relative concentration. This is the ratio of concentration as a function of depth and time to the initial concentration of the solution, as expressed in the equation 2.

$$
\frac{C(z, t))}{c_{0}}=\frac{1}{2}\left\{\operatorname{erfc}\left(\frac{Z-V s t}{2 \sqrt{D} T}\right)+\exp \left(\frac{V s Z}{D}\right) \operatorname{erfc}\left(\frac{Z+V s t}{2 \sqrt{D} T}\right)\right\}(2)
$$

R: Retardation factor; C: Effluent concentration (mg/L); $C_{0}$ : Influent concentration (mg/L); Z: Thickness of the soil; $\mathrm{V}_{\mathrm{s}}$ : Velocity of fluid through soil $(\mathrm{m} / \mathrm{sec})$; $\mathrm{T}$ : time to achieve breakthrough time (Hr); erfc: complementary error function

\section{Materials and methods}

Locally available Black cotton soil ( $\mathrm{CH}$ soil) is obtained from Warangal, Telangana, India were used in the study and properties and the chemical composition of the soil is presented in table 1 and 2 .

\begin{tabular}{|c|c|c|}
\hline Property & IS 2720 & Clayey Soil \\
\hline Gravel $(\%$ & \multirow{3}{*}{ part IV } & 0 \\
\hline Sand $(\%)$ & & 30 \\
\hline Silt $(\%)$ & & 39 \\
\hline Clay $(\%)$ & \multirow{4}{*}{ part V } & 31 \\
\hline Liquid Limit (\%) & & 61 \\
\hline Plastic Limit (\%) & & 21 \\
\hline Plasticity Index & & 40 \\
\hline Classification (IS) & \multirow{3}{*}{ part VII } & $\mathrm{CH}$ \\
\hline $\operatorname{MDD}(g / c c)$ & & 1.7 \\
\hline OMC $(\%$ & & 19.6 \\
\hline Free Swell Index & part $X X X X$ & 50 \\
\hline $\begin{array}{l}\text { CEC (meq/100g) } \\
\mathrm{K}\left(10^{-10} \mathrm{~m} / \mathrm{sec}\right)\end{array}$ & $\begin{array}{l}\text { part XXIV } \\
\text { part XVII }\end{array}$ & $\begin{array}{c}75 \\
0.505\end{array}$ \\
\hline
\end{tabular}

Table 1. Properties of the soil

MDD: maximum Dry density; OMC: Optimum Moisture content; CEC: Cation Exchange capacity; K: permeability

Table 2. Chemical Composition of the $\mathrm{CH}$ soil

\begin{tabular}{cccc}
\hline $\begin{array}{c}\text { Soil } \\
\text { Composition }\end{array}$ & $\%$ & $\begin{array}{c}\text { Soil } \\
\text { Compositio } \\
\mathbf{n}\end{array}$ & $\%$ \\
\hline $\mathrm{SiO}_{2}$ & 43.6 & $\mathrm{~K}_{2} \mathrm{O}$ & 0.63 \\
& & $\mathrm{MnO}$ & 0.47 \\
$\mathrm{Al}_{2} \mathrm{O}_{3}$ & 22.8 & $\mathrm{P}_{2} \mathrm{O}_{5}$ & 0.28 \\
$\mathrm{Fe}_{2} \mathrm{O}_{3}$ & 14.7 & $\mathrm{Na}_{2} \mathrm{O}$ & 0.225 \\
$\mathrm{CaO}$ & 7.5 & $\mathrm{SO}_{3}$ & 0.14 \\
$\mathrm{MgO}$ & 7.3 & & \\
$\mathrm{TiO}_{2}$ & 1.71 & &
\end{tabular}

$\%$ Percentage

\subsection{Chemicals}

All the chemicals used in the present study were analytical grade and the stock solution of $1000 \mathrm{mg} / \mathrm{l}$ were prepared from the salts. From the $1000 \mathrm{mg} / \mathrm{l}$ stock solution, the initial concentration of $30 \mathrm{mg} / \mathrm{l}$ of each heavy metal $\mathrm{Pb}$ (II), Ni (II), Cd (II) and Cr (VI) prepared. The initial concentration was selected mainly because of the maximum heavy metal concentration present in the leachate. The leachate composition presented in table 3.

Table 3. Chemical composition of Leachate

\begin{tabular}{lc}
\hline \multicolumn{1}{c}{ Parameter } & $\begin{array}{c}\text { Concentration } \\
(\mathrm{mg} / \mathrm{l})\end{array}$ \\
\hline Nickel $(\mathrm{Ni})$ & 37 \\
Chromium $(\mathrm{Cr})$ & 22 \\
Cadmium $(\mathrm{Cd})$ & 1.1 \\
Lead $(\mathrm{Pb})$ & 0.7 \\
\hline
\end{tabular}

The $\mathrm{pH}$ of the influent solution was maintained as 2 for $\mathrm{Pb}, \mathrm{Ni}$ and $\mathrm{Cd}$ mainly because, these metals were having less percentage removal at $\mathrm{pH} 2$ ( Liu et al, 2010; Soares et al, 2011; Li et al, 2012; Hamadneth et al, 2015). For $\mathrm{Cr}(\mathrm{VI})$ the $\mathrm{pH}$ was maintained as 7 because of $\mathrm{Cr}(\mathrm{VI})$ having less percentage removal at $\mathrm{pH} 7$ (Gosh et al, 2013). When EDTA present along with heavy metals $(\mathrm{Pb}$, $\mathrm{Ni}, \mathrm{Cd}$ and $\mathrm{Cr}(\mathrm{VI})$ ), the $\mathrm{pH}$ of the solution was maintained as pH 7 because, the EDTA present in 
the solution have low heavy metal adsorption at $\mathrm{pH}$ 7 (Li et al, 2012) and in case of multi heavy metal interaction, the $\mathrm{pH}$ was maintained 2 and 7 . The $\mathrm{pH}$ of the solution was adjusted by using $0.1 \mathrm{M} \mathrm{HNO}_{3}$ and $0.1 \mathrm{M} \mathrm{NaOH}$ solution.

\subsection{Experimental procedure}

Sample preparation and placement in the column Column tests were conducted to determine the transport parameters of the $\mathrm{CH}$ soil. The soil samples were prepared by adding deionized water to the air-dried soils to achieve water content $2 \%$ wetter than the optimum water content in order to obtain the lowest hydraulic conductivity of soil sample (Daniel, 1994; Benson et al, 1999). Substantially, the samples were compacted in accordance with an adaptation of the standard proctor compaction method using a mould of 6.74 $\mathrm{cm}$ diameter and $2 \mathrm{~cm}$ height.

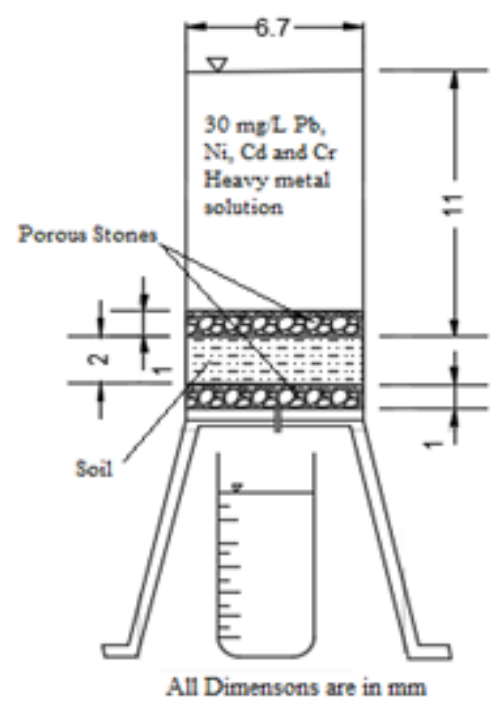

Fig. 1. Small Scale column setup

The sample was permeated initially with DI water in order to achieve the first exposure effect and hence it reduced the hydraulic conductivity of the samples (Shackelford, 1994; Quaranta et al, 1996; Gleason et al, 1997). The flow was induced by maintaining the constant head throughout the experiment. After $24 \mathrm{Hr}$ of Permeation with the DI water, the DI water removed and heavy metal solutions were introduced and then periodically collected the heavy metal effluents and its concentration were analysed by using Agilent made ICP - OES. The schematic representation of the column setup used in the investigation is given in Fig. 1. The column was placed on the stand to remain vertically and sufficiently above the floor for outlet. The column tests were observed up to a point when $90 \%$ of the breakthrough was achieved.

\section{Results and discussion}

The breakthrough curves are plotted between the relative concentration $\left(C / C_{0}\right)$ along ordinate and time along abscissa are shown in figures 2 to 12 . The data used for finding breakthrough curves include the results obtained from the column experiments conducted on $\mathrm{CH}$ in the presence of single and composite metal solution in the presence of EDTA. The diffusion coefficients for each condition was sown in table 4 and 5.

\section{- $\quad$ Single heavy metal interaction}

\section{Nickel (II) solution}

Based on the effluent concentration obtained, breakthrough curve is drawn with respect to time calculated from the starting of experiment to the point of collection expressed in hours for $\mathrm{CH}$ soil. The breakthrough curves are shown in Fig 2 for $\mathrm{CH}$ soil considering only $\mathrm{Ni}$ solution as an incoming synthetic pollutant.

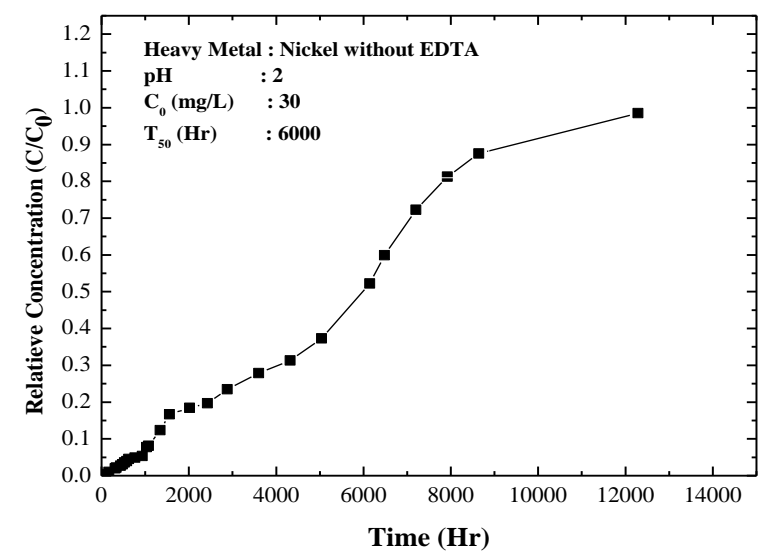

Fig. 2. Breakthrough curve of $\mathrm{CH}$ soil for Nickel (Ni)

It has been observed from the Fig 2 the breakthrough time required for achieving 50\% breakthrough of $\mathrm{Ni}$ for $\mathrm{CH}$ soil is 1200 hours. This is because of higher cation exchange capacity of $\mathrm{CH}$ soil.

- $\quad$ Lead (II) solution

Based on the effluent concentration obtained, breakthrough curve is plotted with respect to time calculated from the starting of experiment to the point of collection of effluent expressed in hours for $\mathrm{CH}$ soil. The breakthrough curve is shown in Fig 3 for $\mathrm{CH}$ soil considering only $\mathrm{Pb}$ solution as an incoming synthetic pollutant.

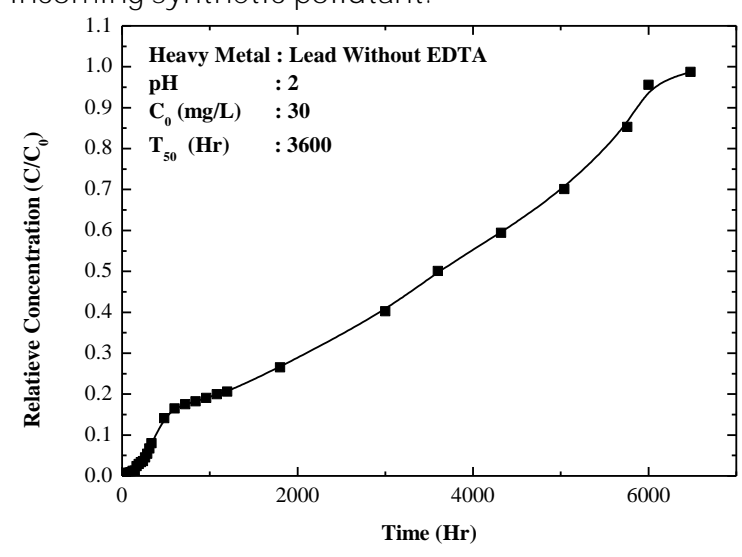

Fig. 3. Breakthrough curve for $\mathrm{Pb}$ 
Similar trend is observed in case of $\mathrm{Pb}$ as in case of $\mathrm{Ni}$ i.e., the delayed breakthrough has been found for $\mathrm{CH}$ soil. Moreover, from Fig 3, it is also observed that $\mathrm{Pb}$ shows more mobility when compared to $\mathrm{Ni}$.

\section{- Cadmium (II) solution}

The breakthrough curve for cadmium is given in Fig 4, in case of $\mathrm{CH}$ soil with mentioning of the time required for achieving 50\%breakthrough.

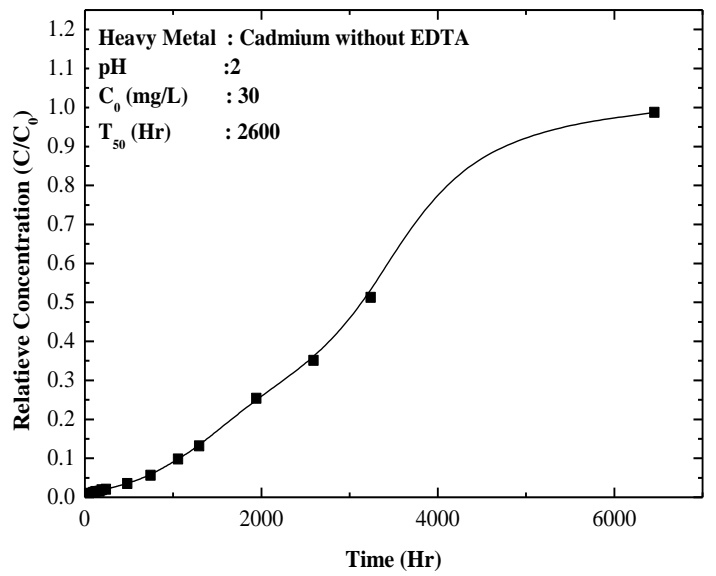

Fig. 4. Breakthrough curve for $\mathrm{Cd}$

The Fig 4 shows the time required to get 50\% break through is $2600 \mathrm{Hr}$. finally the order of migration observed for the three heavy metals such as $\mathrm{Pb}, \mathrm{Ni}$ and $\mathrm{Cd}$ has been given based on the breakthrough time. It has been noticed that, compared to $\mathrm{Pb}$ and $\mathrm{Ni}$, the $\mathrm{Cd}$ is showing more mobility at $\mathrm{pH} 2$ for $\mathrm{CH}$ Soil. At $\mathrm{pH} 2$, the order of heavy metal mobility was $\mathrm{Ni}, \mathrm{Pb}$ and $\mathrm{Cd}$ from low mobility to high mobility.

\section{- Chromium (VI) solution}

The column studies were conducted for hexavalent chromium ( $\mathrm{Cr}(\mathrm{VI}))$ with $\mathrm{pH} 7$.

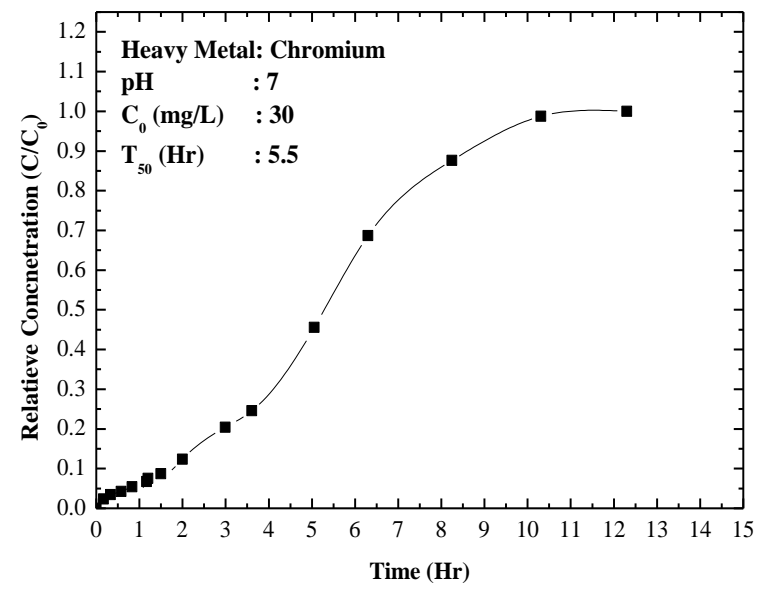

Fig. 5. Breakthrough curve for $\mathrm{Cr}(\mathrm{VI})$

The breakthrough curve obtained from column studies for $\mathrm{Cr}(\mathrm{VI})$ were presented in fig 5. The result shows higher mobility of $\mathrm{Cr}(\mathrm{VI})$ was observed when compared to mobility of $\mathrm{Pb}$ (II), Ni (II) and Cd (II). This is mainly because, as $\mathrm{Cr}(\mathrm{VI})$ is present in anionic from, the $\mathrm{Cr}(\mathrm{VI})$ will repel with negative charged soil surface as a result it will not adsorbed on the soil surface leads to early migration of the $\mathrm{Cr}$ (VI).

By considering all the above results, in the term of breakthrough curves in a single metal system, it can be observed that at $\mathrm{pH} 2$, the decreasing order of mobility for heavy metals expressed as $\mathrm{Ni}<\mathrm{Pb}<$ $\mathrm{Cd}$. This is because, at $\mathrm{pH} 2$, electronegativity of the metal ion plays an important role in getting adsorbed by soil active sites. Higher the electronegativity of metal, the greater chance to get adsorbed by the soil through easier dissociation of $\mathrm{H}^{+}$ion from the functional groups of the soil mineral (Paulo et.al, 2001). The sequence of electronegativity for the three metals are $\mathrm{Ni}$ (1.91) > $\mathrm{Pb}(1.8)>\mathrm{Cd}$ (1.69). The column studies are shows similar behaviour supported by the electronegativity concept. At low $\mathrm{pH}$, the adsorption of $\mathrm{Cd}$ is decreased by the protonation of silica and alumina group i.e. $\mathrm{Si}$ - $\mathrm{O}^{-}$and $\mathrm{Al}$ - $\mathrm{O}^{-}$respectively (Abollino et.al, 2003). On the other hand, the adsorption of $\mathrm{Cr}(\mathrm{VI})$ decreases with increase in $\mathrm{pH}$. This is due to increase of negative charge in the soil solid phase (Sherene 2010) with increase in $\mathrm{pH}$ which leads to higher mobility of (VI) and also the mobility was expected to be increased by probable decrease in the plastic limit of the soil after interaction of $\mathrm{Cr}(\mathrm{VI})$ with the soil. Hence, it increases the hydraulic conductivity of the tested soils due to decrease in the thickness of diffused double layer (Wang P. et al, 2015).

- Composite heavy metal system

In case of composite metal system, four heavy metals ( $\mathrm{Pb}, \mathrm{Ni}, \mathrm{Cd}$ and $\mathrm{Cr}$ ) have been considered for study. The $\mathrm{pH}$ of the final solution was set at 2 by adding $0.1 \mathrm{M} \mathrm{HNO}_{3}$. The composite solution was then transferred to soil column for further study. $\mathrm{pH}$ 2 has been chosen to eliminate the metal hydroxide compound formation. The breakthrough curves are plotted and shown in Fig 6 based on the results obtained from column tests performed on $\mathrm{CH}$ soils.

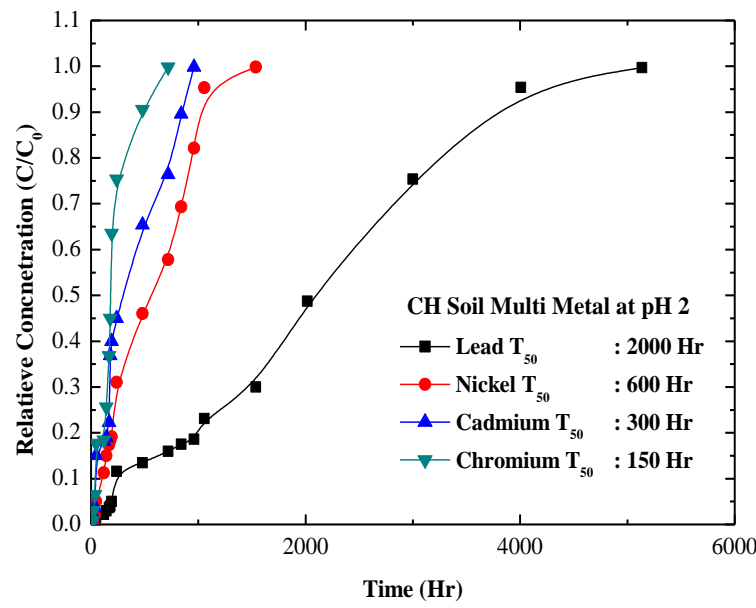

Fig. 6. Breakthrough curve for Composite heavy metal system 
From fig 6, it has been observed that the time required to accomplish half breakthrough for multi metal system is less for multi metal system when compared to single heavy metal system for $\mathrm{CH}$ soil. The reduction in breakthrough time can be observed for three bivalent metal ions i.e. Ni (II), Cd (II) and $\mathrm{Pb}$ (II) and for $\mathrm{Cr}(\mathrm{VI})$, the breakthrough time increases when compared to the result obtained in case of single metal system. This is mainly because, the reduction in adsorption for three heavy metals can be stated by considering the competitive effect between the metals with hydrogen ion $\left(\mathrm{H}^{+}\right)$. At lower $\mathrm{pH}$, due to the presence of hydrogen ion $\left(\mathrm{H}^{+}\right)$ in the soil solution the competition occurs between $\mathrm{H}^{+}$ions and the other three bivalent metals for occupying adsorption sites (Raymond and Yuwaree 1993). As a result, the mobility of three bivalent ions ( $\mathrm{Pb}, \mathrm{Ni}$ and $\mathrm{Cd}$ ) were increased, which leads to quick breakthrough in case of multi heavy metal system. But in case of $\mathrm{Cr}(\mathrm{VI})$ which is present in oxyanionic form, the reverse behaviour can be observed due to the transformation of $\mathrm{Cr}(\mathrm{VI})$ ion into $\mathrm{Cr}$ (III) ion in presence of $\mathrm{H}^{+}$ion. The equilibrium equation for the yielding of trivalent chromium ion at lower $\mathrm{pH}$ is given in equation 3 (Daneshvar et. al, 2002).

$\mathrm{Cr}_{2} \mathrm{O}_{7}{ }^{2-}(\mathrm{aq})+14 \mathrm{H}^{+}(\mathrm{aq})+6 \mathrm{e}^{-}-----\rightarrow 2 \mathrm{Cr}^{3+}(\mathrm{aq})+7 \mathrm{H}_{2} \mathrm{O}$

The newly formed $\mathrm{Cr}$ (III) ion can be retained by the soil through cation exchange process due to its higher positive charge ultimately resulting in greater adsorption of $\mathrm{Cr}(\mathrm{VI})$ present in multi metal system at $\mathrm{pH} 2$.

\section{- $\quad$ Single heavy metal system with EDTA}

To find the effect of synthetic organic compound i.e. EDTA on the mobility of heavy metals passing through the $\mathrm{CH}$ soil. The same procedure was then followed as in case of single metal system without the presence of EDTA. The breakthrough curve obtained based on the available data for each heavy metal separately in the presence of EDTA are presented in figures 7 to 12 .

\section{- $\quad$ Nickel (II) solution with EDTA}

Based on the effluent concentration of $\mathrm{Ni}$ (II) obtained, the breakthrough curve was plotted and presented in Fig 7 for $\mathrm{CH}$ soil.

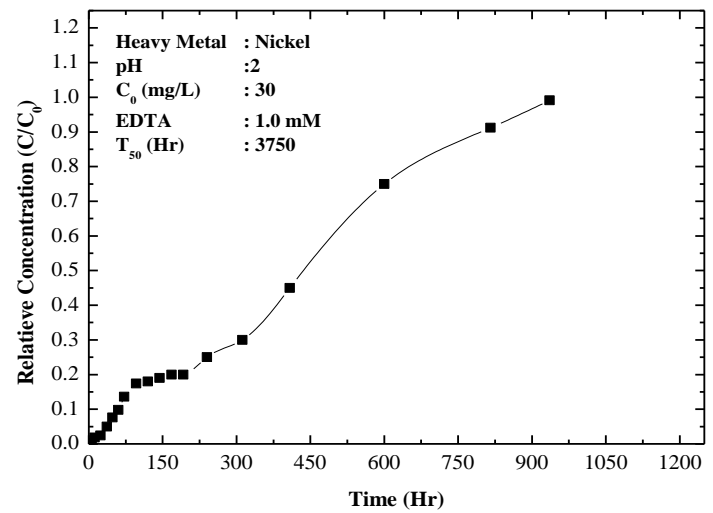

Fig. 7. Breakthrough curve for $\mathrm{Ni}$ (II) in presence of EDTA
From Fig 7 it is observed that, in the presence of EDTA, the time for achieving 50\% breakthrough is reduced compared to the absence of EDTA in single metal system. It can be concluded that the chelating ability of EDTA increase the solubility of $\mathrm{Ni}$ by forming complex product (Kim et.al. 2003).

\section{- $\quad$ Lead (II) solution with EDTA}

The breakthrough curve for Lead (II) in the presence of EDTA is represented in this context. The time required for attaining half breakthrough is also approximately mentioned by sorting it out from the breakthrough curve. The breakthrough curve for $\mathrm{CH}$ soil are shown in Fig 8.

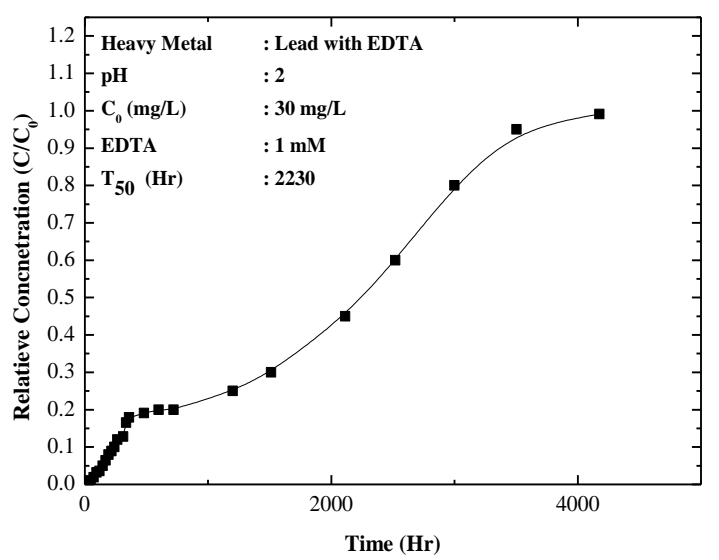

Fig. 8. Breakthrough curve for $\mathrm{Pb}$ (II) in presence of EDTA

From fig 8, it is observed that, the mobility of $\mathrm{Pb}$ (II) increased in the presence of EDTA due to the Pb - EDTA complex formation. The effect of EDTA complexation with metal ion can be quite presumed based on the obtained breakthrough data.

\section{- $\quad$ Cadmium (II) solution with EDTA}

In presence of EDTA, the mobility of Cd (II) can be shown through the breakthrough curve plotted on the basis of the results obtained from column test. The time required for achieving $50 \%$ breakthrough shown in Fig. 9. The breakthrough curve was presented with respect to time expressed in hours. Cd (II) was also not an exception case from the other two bivalent metal ions ( $\mathrm{Pb}$ and $\mathrm{Ni})$. But the reduction in time for achieving half breakthrough due to increase in mobility of metal ions through the formation of stable metal- EDTA complex product was more in case of Cd (II) compared to $\mathrm{Ni}$ (II) and $\mathrm{Pb}$ (II) .

In the presence of EDTA, the increasing order of mobility was observed as: $\mathrm{Cd}$ (II) $>\mathrm{Pb}$ (II) $>\mathrm{Ni}$ (II). The observed behaviour of the three bivalent metals $(\mathrm{Pb}, \mathrm{Ni}$ and $\mathrm{Cd}$ ) can be explained by employing of complexation constant which determines the stability of metal- EDTA complex. The stability constants of $\mathrm{Cd}, \mathrm{Pb}$ and $\mathrm{Ni}$ are 16.5, 18 and 18.6 respectively. The higher the value of complexation constant, the greater will be the chance of forming more stable metal- EDTA complex. The increasing order of the stability constant in case of heavy metal ions is as follow: $\mathrm{Cd}$ (II) $<\mathrm{Pb}$ (II) $<\mathrm{Ni}$ (II) and 
from this as stability constant of metal EDTA complex increased, the mobility of heavy metal is reduced (Nastaran and Alain, 2009).

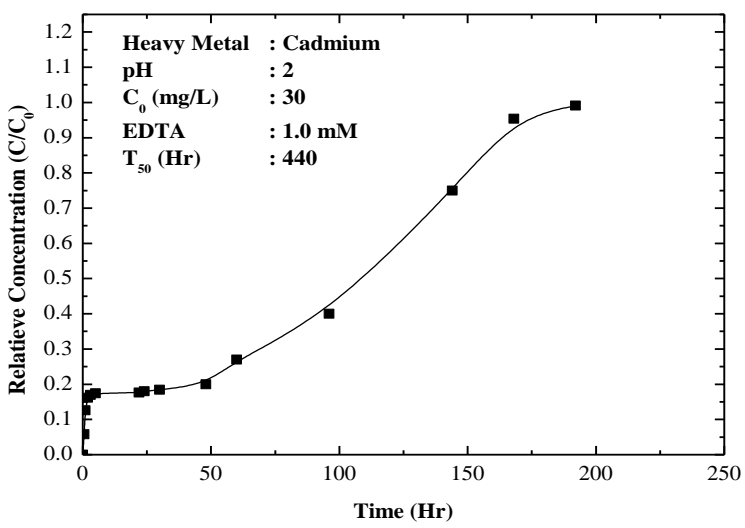

Fig. 9. Breakthrough curve for $\mathrm{Cd}$ (II) in presence of EDTA

\section{- Chromium (VI) solution with EDTA}

The breakthrough curve for hexavalent chromium solution in the presence of EDTA have been shown in Fig. 10. Which shows the time required for 50 \%breakthrough for $\mathrm{CH}$ soil at $\mathrm{pH} 7$.

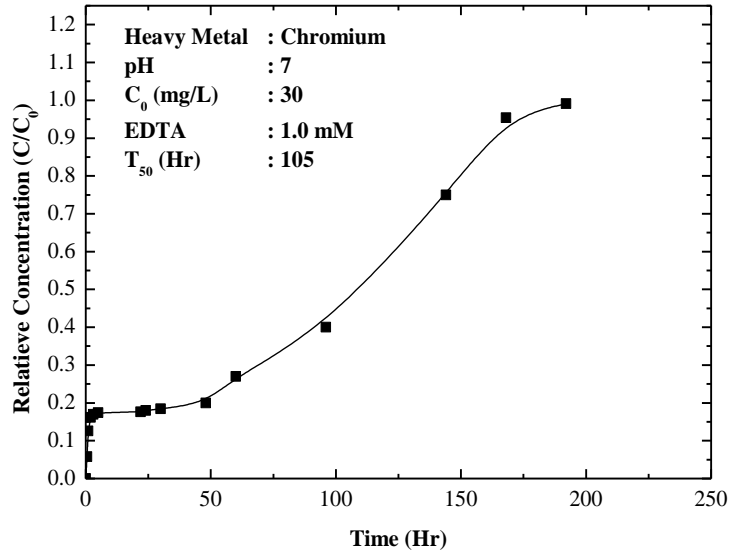

Fig. 10. Breakthrough curve for $\mathrm{Cr}(\mathrm{VI})$ in presence of EDTA

From fig 10, it was observed that, the mobility of $\mathrm{Cr}$ $(\mathrm{VI})$ is reduced in the presence of EDTA in case of $\mathrm{CH}$ soil when compared with without EDTA condition. This is mainly because, at greater $\mathrm{pH}$ the presence of hydroxyl ion $\left(\mathrm{OH}^{-}\right)$may compete with EDTA for complexation with the metal ions which tends to hydrolyse and precipitate as hydroxides (Jose et.al. 2014).

\section{- $\quad$ Composite heavy metal system with EDTA}

The column tests were performed on composite heavy metal system (i.e. Pb (II), Ni (II), Cd (II) and Cr $(\mathrm{VI})$ ) in the presence of EDTA at two different $\mathrm{pH}$ (2 and 7) to know the breakthrough behaviour of heavy metals. All the results obtained from each test are represented in the form of breakthrough curves which are plotted and presented in Fig 11 and 12 .
- $\quad$ Composite heavy metal with EDTA at pH 2

Based on the concentration of effluents and the time of collection of effluents emitting from the soil columns, the breakthrough curves were plotted and further represented in the context.

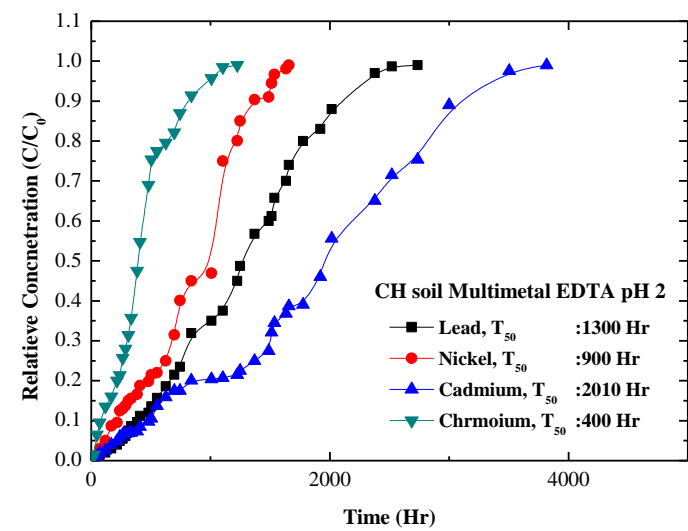

Fig. 11. Breakthrough curve for Composite heavy metal in the presence of EDTA

Form the Fig. 11, it is observed that, there are many variations in the results that can be observed in multi metal system under the influence of EDTA when compared to single metal system in the presence of EDTA. This is mainly due to the competitive effect existing between $\mathrm{Ni}$ (II) and $\mathrm{Pb}$ (II) with other metals and $\mathrm{H}^{+}$ion present in multi metal system and higher complexation constants prevailing in the metal- EDTA complexation reactions for both bivalent metals, the mobility is enhanced in case of $\mathrm{Ni}$ (II) and $\mathrm{Pb}$ (II) for $\mathrm{CH}$ Soil. In case of $\mathrm{Cd}$ (II), this is mainly due to the low stability constant of Cd (II) - EDTA complex product and shortage of free EDTA ions available for complexation while having higher affinity of EDTA towards other bivalent ions. For $\mathrm{Cr}(\mathrm{VI})$, after transforming into trivalent ion i.e. $\mathrm{Cr}$ (III) the chance for forming complex with EDTA is reduced due to increase in its ionic radius compared to $\mathrm{Cr}(\mathrm{VI})$ (Jose et. al 2014).

\section{- $\quad$ Composite heavy metal with EDTA at pH 7}

Comparative analyses have been done based on the results obtained at two different $\mathrm{pH}$ (2 and 7) with supporting expectable reasons which more or less confirm to the explanations provided by the researchers. The break through characteristics of composite heavy metals in the presence of EDTA at $\mathrm{pH} 7$ was presented in Fig. 12, from Fig 12, it is observed that, the break through time is reduced significantly in the presence of EDTA at $\mathrm{pH} 7$ condition when compared with composite heavy metals at $\mathrm{pH} 2$ condition in the presence of EDTA. This is due to the formation of metal EDTA complexes that exist in the solution in the form of negative charged molecule (Bradl 2004), as a result of the negative charged soil surface is competing with the metal EDTA complex leads to the early migration of heavy metals through the soil. 


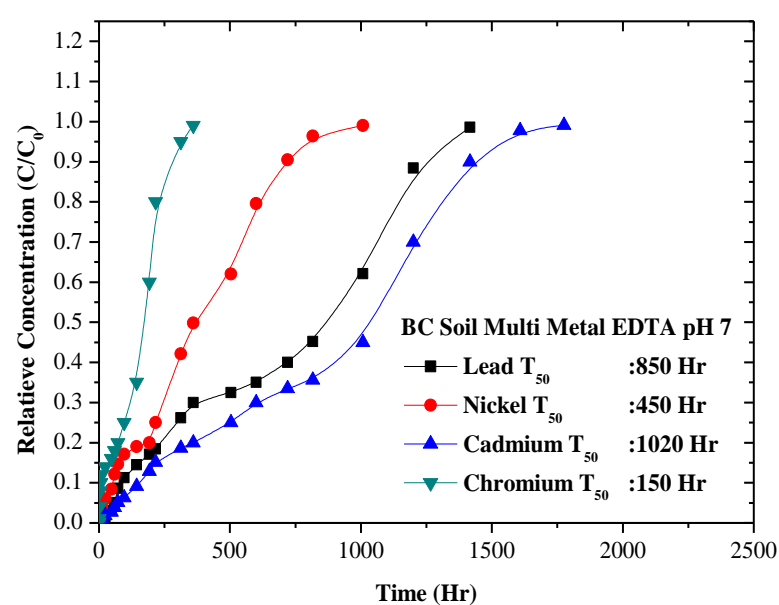

Fig. 12. Breakthrough curve for Composite heavy metal in the presence of EDTA

\section{- Diffusion Coefficient ( $\left.D^{*}\right)$}

The diffusion co-efficient ( $\left.D^{*}\right)$ are calculated by using equation 2 on the basis of $\mathrm{T}_{50}$ (time required to achieve $50 \%$ breakthrough) obtained from each breakthrough curve for the corresponding case (Ramakrishna et.al. 2011). The parameter D* is having greater significance in designing and checking the effectiveness of the landfill liner.

- Diffusion coefficient (D*) for Black cotton soil (CH)

The effective diffusion coefficient (D) calculated for single heavy metal solution interaction is presented in the table 4.

Table 4. Diffusion coefficient for Single metal solution

\begin{tabular}{|c|c|c|}
\hline \multicolumn{3}{|c|}{ Single Heavy metal without EDTA } \\
\hline $\mathrm{pH}$ & Heavy metal & $\mathrm{D}^{*}\left(\mathrm{~m}^{2} / \mathrm{sec}\right)$ \\
\hline 7 & $\mathrm{Cr}$ & $2.45 \times 10^{-08}$ \\
\hline 2 & $\mathrm{Cd}$ & $4.16 \times 10^{-11}$ \\
\hline 2 & $\mathrm{~Pb}$ & $3.50 \times 10^{-11}$ \\
\hline 2 & $\mathrm{Ni}$ & $2.10 \times 10^{-11}$ \\
\hline \multicolumn{3}{|c|}{ Single Heavy metal with EDTA } \\
\hline 7 & $\mathrm{Cr}$ & $1.15 \times 10^{-09}$ \\
\hline 2 & $\mathrm{Cd}$ & $2.74 \times 10^{-10}$ \\
\hline 2 & $\mathrm{~Pb}$ & $5.39 \times 10^{-11}$ \\
\hline 2 & $\mathrm{Ni}$ & $3.18 \times 10^{-11}$ \\
\hline
\end{tabular}

From this table it is observed that the diffusion coefficient is reduced about 1.54, 1.51 and 6.58 times for $\mathrm{Pb}$ (II), Ni (II) and Cd (II) respectively after EDTA present in the influent solution. This is mainly because, when the influent solution passes through the soil column, because of the alkali nature of the soil, the solubility of the metal EDTA complex is increasing as a result, the mobility of the heavy metal increasing. In case of the $\mathrm{Cr}$ (IV), after interacted with EDTA the diffusion coefficient is reduced by 21 times, this is due to the this $\mathrm{Cr}$ (IV) reduces to $\mathrm{Cr}$ (III) after interacting with EDTA and this $\mathrm{Cr}$ (III) forms the precipitated wit in the soil due to the alkali nature of the soil and these precipitates are blocking the flow paths in the soil that leads the decrease in the mobility of $\mathrm{Cr}(\mathrm{VI})$ through the soil column.

The table 5 shows the diffusion coefficients of $\mathrm{CH}$ soil interacted with multi metal solution with and without EDTA at two different $\mathrm{pH}$ conditions (2 and 7).

Table 5. Diffusion coefficient for Multi-metal solution

\begin{tabular}{cc}
\hline \multicolumn{3}{c}{ Multi Heavy Metal at $\mathrm{pH} 2$} \\
Heavy metal & $\mathrm{D}^{*}\left(\mathrm{~m}^{2} / \mathrm{sec}\right)$ \\
\hline $\mathrm{Cr}$ & $6.0 \times 10^{-10}$ \\
$\mathrm{Ni}$ & $2.01 \times 10^{-10}$ \\
$\mathrm{~Pb}$ & $6.10 \times 10^{-11}$ \\
$\mathrm{Cd}$ & $4.02 \times 10^{-10}$ \\
\hline Multi Heavy Metal EDTA at $\mathrm{pH} 2$ \\
\hline $\mathrm{Cr}$ & $3.02 \times 10^{-10}$ \\
$\mathrm{Ni}$ & $1.34 \times 10^{-10}$ \\
$\mathrm{~Pb}$ & $9.25 \times 10^{-11}$ \\
$\mathrm{Cd}$ & $5.98 \times 10^{-11}$ \\
\hline $\mathrm{Multi}$ Heavy Metal EDTA at $\mathrm{pH} 7$ \\
$\mathrm{Cr}$ & $8.6 \times 10^{-10}$ \\
$\mathrm{Ni}$ & $2.68 \times 10^{-10}$ \\
$\mathrm{~Pb}$ & $1.42 \times 10^{-10}$ \\
$\mathrm{Cd}$ & $1.180 \times 10^{-10}$ \\
\hline
\end{tabular}

From this table it is observed that, the mobility of $\mathrm{Pb}$ (II), $\mathrm{Ni}$ (II) and Cd (II) increased about 1.74, 9 and 9.5 time when compared to single metal solution. The mobility of $\mathrm{Cr}(\mathrm{VI})$ decreased when compared with the single heavy metal solution. This is mainly due to the complex formation with the other heavy metals. From the table 5 it can also observed that, the mobility is decreased when the $\mathrm{CH}$ soil interacted with the multi metal solution with EDTA at $\mathrm{pH} 2$ this is mainly because, at $\mathrm{pH} 2$ most of the metal - EDTA complexes are not that much strong and these metal - EDTA complex will get precipitated at $\mathrm{pH} 2$ that leads to decrease in the mobility of metal trough the soil column. The multi metal solution with EDTA at pH 7, the mobility got increased about 2.3, 1.3 and 1.43 times respectively for $\mathrm{Pb}$ (II), $\mathrm{Ni}$ (II) and $\mathrm{Cd}$ (II) the mobility got decreased about 3 times because of the competition between metal EDTA complexes. Table 5 also shows the mobilization of heavy metals through the soil column under the influence of EDTA at pH 2 and 7. The mobility of heavy metals are increased about $1.53,2,1.97$ and 2.84 times respectively for $\mathrm{Pb}$ (II), $\mathrm{Ni}$ (II) and Cd (II) compared with $\mathrm{pH} 2$ condition. This is mainly because, the stable metal complex formation lead to early migration of the heavy metal migration through the soil column. These diffusion coefficients can be effectively used to predict the migration of heavy metals along the thickness of the liner (1-D case). Hence, it also provides a quite 
precise idea about choosing the appropriate design specifications of the liner that can be installed in the landfill area under the prevailing environmental conditions. Although the values determined by using the advective- diffusion equations can reliably be used, somehow it over predicts the value of diffusion coefficient as the seepage velocity term included in the equation was calculated by considering initial hydraulic conductivity.

\section{Conclusions}

1. Breakthrough behaviour of heavy metal depends upon several factors such as $\mathrm{pH}$ of the soil and heavy metal solution, initial concentration of the metal solution, bed depth of the liner provided in the landfill, presence of organic ligand in the landfill waste, existence of other heavy metals and physical and mineralogical properties of the soil.

2. At lower $\mathrm{pH}$, the adsorption of metal ions mainly takes place through cation exchange process which in-turn depends upon the electronegativity of the metal. While at higher $\mathrm{pH}$, immobilization of heavy metals occurs through hydroxide precipitate formation which also indirectly depends upon the radius of first hydrolyzed product of metal.

3. In multi-metal system, the cause for attaining quick breakthrough can be explained by the competitive effect between the other heavy metal ions and hydrogen ion $\left(\mathrm{H}^{+}\right)$for occupying the adsorption sites of the soil.

4. The chelation effect of EDTA to form metalEDTA complex product depends upon various factors such as the type of metal, the size of metal ion, $\mathrm{pH}$ of the solution and magnitude of complexation constant which determines the rate of complexation reaction.

5. Soil having higher cation exchange capacity (CEC) generally increases the breakthrough time by providing more adsorption sites for metal ions. $\mathrm{CH}$ soil is having higher cation exchange capacity that makes it capable of retaining more bivalent metal ions ( $\mathrm{Pb}, \mathrm{Ni}$ and Cd) considered for study. But for hexavalent chromium ion, mobility is increasing in case of $\mathrm{CH}$ soil due to repulsion between its oxyanionic form and negative charges on the soil surface.

\section{Single Heavy metal solution:}

1. For $\mathrm{CH}$ soil, the order of selectivity for three heavy metals ( $\mathrm{Pb}, \mathrm{Ni}$ and $\mathrm{Cd}$ ) is observed as $\mathrm{Pb}$ $>\mathrm{Ni}>\mathrm{Cd}$ at $\mathrm{pH} 2$. For $\mathrm{Cr}(\mathrm{VI})$, it shows more mobility at $\mathrm{pH} 7$. For bivalent metal ions $\mathrm{pH} 2$ was considered as that $\mathrm{pH}$ at which immobilization of metals can possibly occur through cation exchange process rather than hydroxide formation and same case happens for hexavalent chromium (VI) at $\mathrm{pH}$ 7. Although the effective diffusion coefficients (D*) itself show the greater mobility in case of $\mathrm{Cr}(\mathrm{VI})$ at $\mathrm{pH} 7$ compared to other three heavy metals.
2. In presence of EDTA, the breakthrough time get reduced due to soluble metal-EDTA complex formation. The order of mobility for bivalent ions in this case is observed as $\mathrm{Ni} \geq \mathrm{Pb}>\mathrm{Cd}$ at $\mathrm{pH}$ 2. The effect of EDTA on mobilizing $\mathrm{Cr}(\mathrm{VI})$ at $\mathrm{pH} 7$ was comparatively more pronounced from the aspect of effective diffusion coefficient (D*) than other heavy metals at $\mathrm{pH} 2$ condition.

3. $\mathrm{CH}$ soils show almost same breakthrough behaviour for four heavy metals in presence of EDTA.

\section{Multi-Heavy metal solution:}

1. At $\mathrm{pH} 2$, the transformation of $\mathrm{Cr}(\mathrm{VI})$ into $\mathrm{Cr}$ (III) after reacting with $\mathrm{H}^{+}$cause some sort of adsorption what is not happening at $\mathrm{pH} 7$ in case of single metal solution. The other three bivalent heavy metals are showing more mobility in case of multi-metal system due to competitive effect between the metal ion with other ions and hydrogen ion for occupying active sites of the soils.

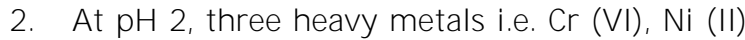
and $\mathrm{Cd}$ (II) are showing less mobility in presence of EDTA when compared to multimetal solution without EDTA except for Pb (II) where the higher mobility has been observed at $\mathrm{pH} 7$.

\section{REFERENCES}

Abollino O., Acceto M., Malandrino M., Sarzanini $C$ and Mentasi E., 2003. Adsorption of heavy 16 metals on Na-montmorillonite. Effect of $\mathrm{pH}$ and organic substances. Water Research, 37(7), pp.1619-1627.

Benson C. H., Daniel D. E and Boutwell G. P., 1999. Field Performance of compacted clay liner. Journal of Geotechnical and Geo - Environmental Engineering, 125(5), pp. $390-403$

Bowers A. R and Huang C. P., 1985. Adsorption Characteristics of Metal - EDTA complexes onto Hydrous Oxides. Journal of Colloid and Interface Science, 110(2), pp. 575 - 590.

Bradl H. B., 2004. Adsorption of Heavy metal ions om soils and soil sediments. Journal of Colloid and interface science. 277, pp. 1 - 18.

Chen S. S., Hsu H. D., Lin Y.J and Chin P. Y., 2008. "Removal of EDTA from low pH printed-circuit board wastewater in a fluidized zero valent Iron reactor". Water Science and Technology, 58(3):pp.661-667.

Daneshvar N., salari D., Aber S., 2002. Chromium adsorption and $\mathrm{Cr}(\mathrm{VI})$ reduction to trivalent chromium in aqueous solutions by soya cake. Journal of Hazardous Materials, B94; pp. 49 - 61.

Daniel D. E., 1994. State of the art: Laboratory hydraulic conductivity tests for saturated soils. Hydraulic conductivity and waste contaminant transport in soil, ASTM STP 1142, pp.30 - 78.

Gleason, M. H., Daniel, D. E and Eykholt, G. R., 1997. Calcium and sodium bentonite for hydraulic containment applications. Journal of Geotechnical and Geo-environmental Engineering, ASCE 123 (5), 438445.

Goodall D. C and Quigly R. M., 1997. Pollutant migration from two sanitary landfill sites near Sarnia, Ontario. Canadian Geotechnical Journal, 14, pp. 223 - 236.

Gosh S., Mukherjee S., Al - Hamdan A. Z and Reddy K. R. 2013. Efficiency of fine grained soil as landfill liner 
material for containment of chrome tannery sludge. Geotech Geologic engineering, 31, pp.493 - 500.

Hamadneth I., Zurayk R. A., Irmaileh B. A., Bozeya A and Al - Dujaili A. H., 2015. Adsorption of Pb (II) on raw and organically modified Jordanian bentonite. Clay Minerology, 50, pp.485 - 496.

IS 2720-IV., 2006. Indian Standard Methods Of Test For Soils (IS: 2720 (Part IV) - 1985 (Reaffirmed 2006)). pp.1-43.

IS 2720-V., 2006. Indian Standard Methods Of Test For Soils (IS: 2720 (Part V) - 1985 (Reaffirmed 2006)). pp.1-20.

IS 2720-VII., 2011. Indian Standard Methods Of Test For Soils (IS: 2720 (Part V) - 1980 (Reaffirmed 2011)). pp.1-16.

IS 2720-XL., 2002. Indian Standard Methods Of Test For Soils (IS: 2720 (Part V) - 1977 (Reaffirmed 2002)). pp.1-10.

IS 2720-XVII., 2002. Indian Standard Methods Of Test For Soils (IS: 2720 (Part XVII) - 1986 (Reaffirmed 2002)). pp.1-18.

IS 2720-XXIV., 2010. Indian Standard Methods Of Test For Soils (IS: 2720 (Part XXIV) - 1976 (Reaffirmed 2010)). pp.1-11.

Jose E. R., Mateus A. G., Luiz C. A. O., Elaine F. F. C and Teodorico C. R., 2014. Use of Ethylene Diamine Tetra Acetic Acid as a Scavenger for Chromium from "wet Blue" Lather Waste: Thermodynamic and Kinetic Parameters. Journal of Chemistry, 2014, pp. 1 - 8.

Koerner, R. M. and Daniel, D.E., 1993. Manufacturing and construction quality control and quality assurance of geosynthetics. Proceedings GRI-6, MQC/MQA and CQC/CQA of Geosynthetics, 1-14.

Kumar P. R and Singh D. N., 2005. A Novel technique for monitoring contaminant transport through soils. Environmental monitoring and assessment, 109; pp: $147-160$.

Li X., Yang L., Yanfeng, Ye. Z and He A., 2012. Efficient Removal of $\mathrm{Cd}^{2+}$ from Aqueous Solutions by adsorption on PS-EDTA Resigns: Equilibrium, Isotherms, and Kinetic Studies". Journal of Environmental Engineering ASCE 138(9), pp. 940 - 948

Liu Y., Li H and Zhu X. H., 2010. Competitive Adsorption of $\mathrm{Ag}^{+}, \mathrm{Pb}^{2+}, \mathrm{Ni}^{2+}$, and $\mathrm{Cd}^{2+}$ ions on vermiculite. Separation Science and Technology, 45(2), pp.277 - 287.

Marina I., Margherita L., Angle N and Alfredo P., 2003. Toxicity Identification evaluation of leachates from municipal solid waste landfills: A multispecies approach. Chemosphere. 52, pp. 85 -94.

Mohamed, A.M.O and Antia, H.E., 1998. Geoenvironmental Engineering, 82, Elsevier science, Netherlands.

Mohamedzein Y. E. A., Al - Rawas A. A., Al - Aghbari Mohammad Y., Ahmed Q and Abdul H.A. R., 2005. Assessment of crushed shales for use as compacted landfill liners. Engineering Geology, 80(3-4): pp.271281.

Mulligan C. N., Yong R. N and Gibbs B. F., 2001. Remediation technologies for metal contaminated soils and ground water: an evaluation. Engineering Geology, 60, pp. 193 - 207.

Nastaran M and Alain B., 2009. EDTA in soil science: A review of its application in soil trace Metal studies. Terrestrial and Aquatic Environmental toxicology (Global Science Book).

Ogata A and Banks R. B., 1961. A solution of the differential equation of longitudinal dispersion in porous media. U. S. Geological Survey Professional paper $411-$ A, U. S. Geological Survey, Washington. D. C.
Oviedo C and Rodríguez J., 2003. EDTA: The chelating agent under environmental scrutiny. Quimica Nova, 26(6): pp.901-905.

Paulo C. G., Mauricio P. F. F., Aberbal G. S., Eduardo S. M and Andre R. N., 2001. Selectivity sequence and competitive adsorption of Heavy metals by Brazilian soils. Journal of soil science society of America, 65, pp. $1115-1121$.

Peters R. W and Shem L., 1992. Adsorption/Desorption characteristics of lead on various types of soil. Environmental Progress and Sustainable Energy, 11(3): pp.234-240.

Peters R.W., 1999. Chelant extraction of heavy metals from contaminated soils. Journal of Hazardous Materials, 66(1-2): pp.151-210.

Quaranta, J., Gabr, M., Bowders, J., 1996. First exposure performance of the bentonite component of a GCL in a low-pH, calcium-enriched environment. In: Well, L.W. (Ed.), Testing of Geo-synthetic Clay Liners, ASTM STP 1308. ASTM, West Conshohocken, PA, pp. 162-177.

Rajesh R. P., Lewlyn L. R. R., Asish O. M and Sunith H., 2014. Impact of urbanization on municipal solid waste management: A system Dynamic Approach. International journal of Renewable Energy and environmental engineering, 2(1), pp. 31 - 37.

Ramakrishna C. H., Naik M., Sumalatha J and Sivapullaiah V., 2011. Diffusion coefficient of ions in migration through soil liners. International Journal of the Physical Sciences Vol. 6(30), pp. 7044 -7054

Raymond N. Y and Yuwaree P., 1993. pH influence on selectivity and retention of heavy metals in some clay soils. Canadian Geotechnical Journal, 30(5), pp.821 833.

Reddy K. R., Chaparro C and Saichek R. E., 2003. Removal of mercury from clayey soils using electro kinetics. Part A, Toxic/hazardous substances and environmental engineering, Journal of environmental science and health, 38(2): pp.307-338.

Reddy K. R., Danda S., Yukselen - A.Y and Al- Hamdan A.Z., 2010. Sequestration of heavy metals in soils from two polluted industrial sites: implications for remediation. Land Contamination and Reclamation, 18(1): pp.1323.

Rowe, R.K., 2005. Long-term performance of contaminant barrier systems. Géotechnique, 55(9), 631-638.

Shackelford C. D., 1994. Critical Concepts for column testing. Journal of geotechnical engineering, 120 (10), pp. $1804-1828$.

Shackelford, C.D., 1994. Waste soil interactions that alter hydraulic conductivity. In: Daniel, D.E., Trautwein, S.J. (Eds.), Hydraulic Conductivity and Waste Containment Transport, ASTM STP 1142. ASTM, West Conshohocken, PA, pp. 111-168.

Sherene T., 2010. Mobility and transport of heavy metals in polluted soils environment. Biological Forum - an International journal, 2(2), pp. $112-121$.

Soares R. M., Casagrande J. C and Mouta E. R., (2011. Nickel Adsorption by variable charge soils: effect of $\mathrm{pH}$ and ionic strength. Brazilian Archives of Biology and Technology, 54(1), pp. $207-220$.

Wang $\mathrm{P}$ and Keller A., 2008. Particle-size dependent sorption and desorption of pesticides within a watersoil-nonionic surfactant system. Environmental science and technology, 42(9): pp.3381-3387.

Wang P, Xue Q, Li J. S and Zhang T. T., 2015. Effect of pH on leaching behaviour of compacted cement solidification/ stabilization lead contaminated soil. Environmental Progress and Sustainable Energy, 35(1), pp. 149 - 155. 